OOPEN ACCESS

International Journal of Management \& Entrepreneurship Research

P-ISSN: 2664-3588, E-ISSN: 2664-3596

Volume 3, Issue 2, P.No. 30-44, February, 2021

DOI: 10.51594/ijmer.v3i2.199b

Fair East Publishers

Journal Homepage: www.fepbl.com/index.php/ijmer

\title{
EXAMINING THE DIFFERENT FACTORS OF THE MID- TERM PERFORMANCE OF DEVELOPMENT PROJECTS IN VERY POOR COUNTRIES
}

\author{
Dr. Mahamadi Nanema ${ }^{1}$, Dr. Théophile Bindeouè Nassè ${ }^{2}$,Prof. Alidou Ouédraogo ${ }^{3}$ \\ ${ }^{1}$ Norbert Zongo University, Koudougou (Burkina Faso) \\ ${ }^{2}$ University of Business and Integrated Development Studies, Wa (Ghana) \\ ${ }^{3}$ University of Moncton, Moncton (Canada)
}

Corresponding Author: Dr. Théophile Bindeouè Nassè ${ }^{1}$

Corresponding Author Email: nassetheophile2009@gmail.com

Article Received: 13-01-21 Accepted: 29-01-21 Published: 05-03-2021

Licensing Details: Author retains the right of this article. The article is distributed under the terms of the Creative Commons Attribution-Non Commercial 4.0 License (http://www.creativecommons.org/licences/by-nc/4.0/) which permits non-commercial use, reproduction and distribution of the work without further permission provided the original work is attributed as specified on the Journal open access page.

\begin{abstract}
The main purpose of this paper is to examine the factors of performance in the development projects of the very poor countries in general and in particular in the context of Burkina Faso. It is about the identification of the internal and external factors that explain the level of midterm performance of the development projects. The methodology is focused on a quantitative approach with a limited sample of 35 respondents due to some professional and technical problems. The research results show, first, that there are two internal factors to project management namely the planning variable and the Human resources management variable that positively and significantly influence mid-term performance of development projects in Burkina Faso. Second, with con identified external factors, the variable environment or area of project intervention influences positively and significantly the mid-term performance of development projects in Burkina Faso. The recommendation is that these factors should be considered by development project managers and governmental authorities.
\end{abstract}

Keywords: Mid-term performance, Project, Development Project, World Bank, Burkina Faso. 


\section{INTRODUCTION}

The challenge of performance in the projects located in developing countries is emphasized by some researchers such as Nassè (2015), Bande and Nassè (2020) and Carbonell et al. (2020). Nassè (2015) shows that fair practices have some effects on economic performance. Bande and Nassè (2020) underline the links between development communication and performance, and Carbonell et al. (2020) find some relationships between recruitment methods and performance. In the Western context, Bourguignon (2000) also underlines the links between performance and management control, but Lorino (2003) shows that performance is influenced by methods and competencies. For Bouckaert and Halligan (2008) performance should be well managed for good success. Cohanier, Lafarge, and Loiseau (2010) bring out some relationships between management and performance. Jacquet (2011) examine how performance could be well managed perfectly in such a context. However, in the context of Burkina Faso, there is no study that brings out the factors of the mid-term performance and development projects. The present research aims to bring out the factors of the mid-term performance of development projects in developing countries.

The main research question is: What are mid-term performance factors for development projects in Burkina Faso?

Based on a real observation on the research ground, the general objective of this study is to contribute to the mid-term performance of development projects in developing countries in general, and in particular in Burkina Faso. To achieve this, it sets specific objectives.

The specific objectives of this research are:

- to identify the factors that significantly influence the mid-term performance of development projects in Burkina Faso;

- to establish the degree of influence of these factors on the mid-term performance of development projects;

- to offer managerial approaches to stakeholders for better performance management of development projects.

\section{LITERATURE REVIEW}

\section{Conceptual Framework}

The concept of performance of a project: In the same order of difficulty as the definition of the concept of general performance, the concept of "project performance" is also much more used than defined by professionals and theorists in project management. It seems to be an acquired notion that the actors of the field who do not dwell enough on its definition. By way of illustration, the concept of performance is used by the PMBOK hundreds of times without it giving a definition. From the literature review, we have identified some analyzes and definitions of the concept of "project performance". Efficiency is understood as the extent to which resources (inputs) are transformed into results (outputs) in an economical manner. Effectiveness is the extent to which the results have contributed to the achievement of the predefined objectives in the project. Also, it should be noted that the same dictionary adds to the definition of project performance, the criterion of relevance and consistency. Relevance includes the notion of the adequacy of the objectives of the project in relation to its environment. It is the concordance between the objectives, the expectations of the beneficiaries, users and the priorities displayed by the project. Coherence relates to the consistency of the objectives of the 
project with the means implemented. Efficiency is related to cost, time and to the quality of the deliverable. As a matter of fact, Nassè (2016) shows that quality is an has an effect on performance. Effectiveness relating to social and environmental acceptability, their structuring impact and the development of knowledge. These authors also add that for project management professionals, performance comes down to respecting costs, deadlines and quality: the triple constraint triangle. Descheemaekere (2013) defines a high-performance project as one that is completed over time, respecting the budget and the initial scope. The constant e s previous definitions of performance are: cost-quality- and time.

An evolution of the definition comes from Prudhomme (2006) for whom the performance of a project always takes into account the three factors such as respect for costs, completion in the allotted time, and in the expected quality. The techniques and skills of project management can also be important explanatory factors.

For the purposes of this research, compliance with the triple constraint triangle is an important factor in project performance. Since it is interested in development projects, the results generated (outputs) by the project must be much greater than the resources committed to its implementation (inputs). We also draw a line between project success and project performance. The success of a project refers to the achievement of objectives by the project manager and his team, even without observing the performance triangle (quality, cost and time). While performance refers to the technical appreciation of senior management or stakeholders in relation to cost, time and quality (Kiemtore, 2016). It is a technical assessment of the project from the point of view not only of effectiveness, but also of efficiency.

However, in the logic of our postulate, it is imperative to consider managerial factors (management of individuals, teams, etc.) as determining factors in the search for the performance of development projects. The performance of the project is, in other words, the respect of the constraints of cost, time, and quality by the effective implementation of an adequate managerial strategy.

\section{The Concept of Development Project}

Development project refers for sustainable project that are built for the social well-being of a given community (Bessette, 2004; Mc Call, 2010). For Bande and Nassè (2020) development projects are project that achieve better results that could influence sustainable development, profitable for different type of generations such as the present generations and future generations.

\section{Research Hypothesis}

The development of the hypothesis is a work of thinking. It is the anticipated interpretation of the phenomena that we are studying. This means that the hypothesis is in a creation of mind and a provisional design up to that a careful verification of the facts takes away the anticipation character and to level its provisional status, definitively accepted as scientific truth. Based on the literature review, we state the following hypotheses:

- H1: project planning is an internal factor in the mid-term performance of development projects in Burkina Faso;

- H2: human resources management within the projects is one of the internal factors of mid-term performance of development projects;

- H3: variables linked to the project environment influence the mid-term performance of development projects in Burkina Faso; 
- H4: the influence of factors on the performance at mid-term performance of development projects varies depending on the field of project intervention.

\section{Choice and Presentation of the Analysis Model}

We present in this part of the analysis model that will allow us to assess the performance at midterm projects implemented with funding from the World Bank in Burkina Faso. This model is largely inspired by the systemic model as well as the very definition of project management given by Standard ISO 10006. The model relates three types of variables:

1) the explained variable;

2) the explanatory variables;

3) the intermediate or moderating variable.

\section{The Explained Variable or Dependent Variable}

The explained variable of our study is "the performance of development projects executed with World Bank financing in Burkina Faso". It does not require any particular justification, but rather to be explained. Hence the interest in moving to the choice of explanatory variables.

\section{Explanatory Variables or Independent Variables}

These are the variables that explain the performance of development projects. The literature review allowed us to identify several variables. It is:

- The Project Planning variable (project schedule / map): The research devoted to the relationship between planning and corporate performance have multiplied and that led to the observation of better economic performance for planning companies compared to nonplanning ones. In fact, the question of the relationship between planning and business performance has been a topic of increasing interest to strategic management researchers over the past three decades. The results obtained turned out to be inconclusive and often contradictory.

- The Human Resources Management variable of the project: The theoreticians and practitioners of organizational management agree, in fact, to maintain that HR (human resources), when they are managed adequately and in a strategic manner, would contribute to the 'improvement of organizational performance. However, in the midst of this generalized trend, defending the strategic role and the growing importance of HRM (Human Resources Management) in the performance of organizations, the results of certain studies in the context of project management, in particular those Belout and Gauvreau (2004), gave rise to much controversy vis- to -vis the importance of the Human Resources Management, in concluding that it had no significant impact on project success. This variable refers to the need to ensure adequate staffing and training of human resources for the project. The project manager must ensure that these human resources have the skills and motivation to carry on their functions within the team.

- The Project environment variable: It takes into account the conditions and characteristics of the environment in which the projects are implemented. The definition of this variable is necessary because in several cases, the same project carried out in different regions has different performance scores.

\section{Moderating Variable}

It is a variable that influences the impact of the explanatory variables (performance factors) on the explained variable (project performance). In our research, we retained the area of 
intervention. Pinto and Covin (1989) examined the effect of project characteristics, including area of intervention, on project success. A comparison between the projects in the field of construction and in the field of R \& D was therefore carried out. The results of their study showed that, although some critical success factors seem to be common to the two types of projects studied (construction projects and $\mathrm{R} \& \mathrm{D}$ projects), there are significant differences in the importance of these factors. They suggested that it is important to take into account the industry, among other project characteristics, in future research. Belout and Gauvreau (2004), for their part, concluded that the activity sector plays a moderating role in the relationship between the success factors and the success of the project.

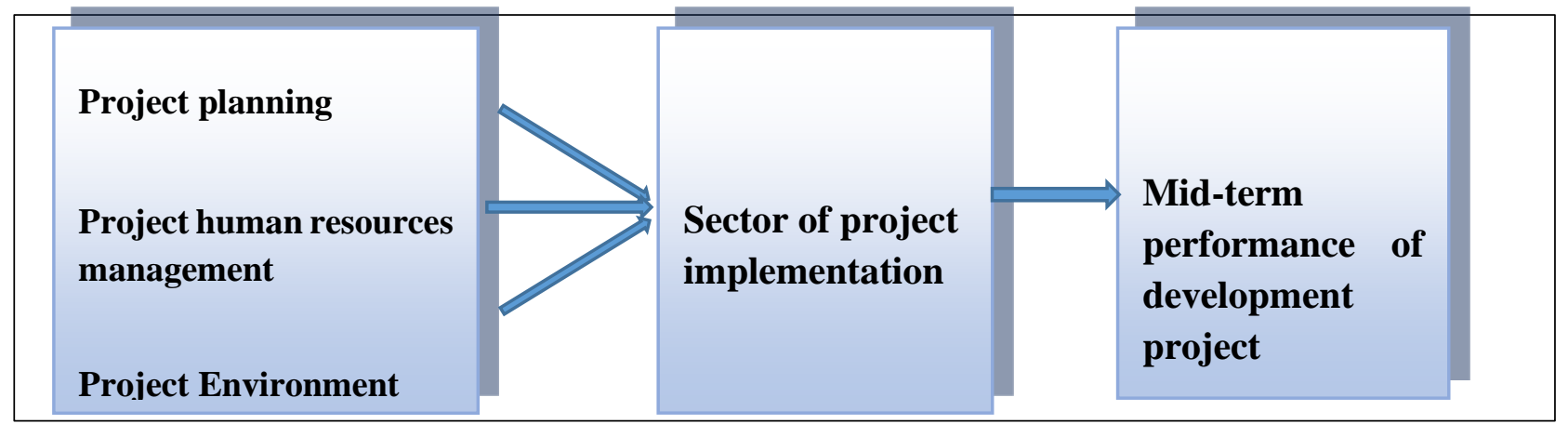

Figure 1: Analysis model

Source: Authors' construct

\section{METHODOLOGY}

Choice of measuring instruments: A questionnaire was chosen as a measuring instrument. The questionnaire is an adaptation of the PIP proposed in the study by Slevin and Pinto (1986). The questionnaire is made up of the following four sections:

- Sociodemographic characteristics of the respondent: sex, age, seniority, education.

- Descriptive data on the project: organizational structure, area of intervention, budget.

- Parameters of performance at mid-term projects: the questions in this section refer to indicators to measure the presence or absence of activities or practices related to the performance parameters at mid-term of the model.

- Performance at mid-term of the project: the questions in this section to verify the presence or absence of performance criteria for mid-term of the project (which is not the dependent variable in our model).

The independent variables and the dependent variable, in sections 3 and 4, are made up of 3 to 5 indicators (formulated in terms of questions) that are measured on a Likert scale in 5 levels. A scale of Likert is an interval scale which "suggests respondents to express their opinion in through a level of agreement with a proposal" (Gavard-Perret et al. 2008). In our questionnaire, the answer is 1 to the notice "not at all agree" then the answer 5 refers to the opinion "all to agree," 3 being a neutral opinion (neither agree nor at variance). 0 The answer as to it is selected when the question does not apply to the respondent. The use of a questionnaire has the advantage of being able to reach a large number of respondents which makes it possible to constitute a fairly large sample. In addition, it has the great advantage of being able to measure a large number of variables using the same questionnaire. 
Moreover, the use of a questionnaire has the advantage of being able to compile the data collected in statistical software such as SPSS, thus making it possible to facilitate statistical analyzes (Gavard-Perret et al. 2008; Gauthier, 2003). It also makes it possible to limit biases linked to the researcher since the respondent cannot be influenced by the presence of the researcher when filling out the questionnaire. Similarly, it makes it possible to limit the biases linked to the variability of recording responses since the response methods are invariant from one respondent to another and from one interviewer to another. Another advantage of the self-administered questionnaire lies in the fact that the responses are directly comparable from one respondent to another, which is a necessary condition for any statistical processing (Gavard-Perret et al. 2008). The administration of the questionnaires, used to collect the data for our study, was carried out according to two methods of distribution that is, sending the digital version to resource persons and distributing it in person.

The sampling plan: Due to the absence of a sampling frame allowing to constitute a probability sample and because of the difficulty in finding the individuals being the subject of the study, we chose a non-probability sample of sixty (60) individuals. From the list offered to us by the World Bank, in addition to our own knowledge. But given the professional difficulties and the techniques used to administer the questionnaire, thirty-five (35) individuals actually participated in the survey. For the sake of representativeness, we ensured that those responsible for development projects in the fields of agriculture, infrastructure construction and health were represented in our sample.

Table 1

Statistics According to the Position Held in the Project and the Execution Sector

\begin{tabular}{lcccc}
\hline \multicolumn{1}{c}{ Position in the project } & \multicolumn{3}{c}{ Project execution sector } & TOTAL \\
\cline { 2 - 4 } & $\begin{array}{c}\text { Education and } \\
\text { Health }\end{array}$ & $\begin{array}{c}\text { Infrastructure and } \\
\text { transport }\end{array}$ & $\begin{array}{c}\text { Rural } \\
\text { development }\end{array}$ & 08 \\
\hline Project coordinator & 02 & 02 & 01 & 03 \\
\hline $\begin{array}{l}\text { Responsible for internal control } \\
\text { in the project }\end{array}$ & 00 & 02 & 04 & 08 \\
\hline $\begin{array}{l}\text { Responsible for monitoring and } \\
\text { evaluation in the project }\end{array}$ & 02 & 02 & 04 & 08 \\
\hline $\begin{array}{l}\text { Responsible for contracts in the } \\
\text { project }\end{array}$ & 02 & 02 & 04 & 08 \\
\hline $\begin{array}{l}\text { Responsible for socio- } \\
\text { environmental affairs in the } \\
\text { project }\end{array} \quad 02$ & 02 & 17 & 35 \\
\hline \multicolumn{1}{c}{ TOTAL } & 08 & 10 & 04 \\
\hline
\end{tabular}

Source: Fieldwork data, 2018

Reliability analysis: This section presents the internal consistency for each of the variables included in our model. The reliability analysis makes it possible to study the properties of measurement scales and of the elements that constitute them. It helps determine how closely the items in a questionnaire relate to each other and provides a general index of the consistency or internal consistency of the scale as a whole.

It is measured using the Alpha coefficient of Cronbach (Gauthier, 2003; Nassè, 2018). This coefficient makes it possible to check the homogeneity of each of the constructs based on the average correlation between the indicators of the construct. The reliability analysis procedure on SPSS calculates several frequently used measures of the reliability of the scale. The table 
below presents the measurements of the Cronbach's Alpha coefficient for each of the constructs of our model.

Table 2

Cronbach's Alpha coefficients

\begin{tabular}{lccc}
\hline \multicolumn{1}{c}{ Variables } & Combrach's Alpha & Number of Valid cases (n) & Number of Items \\
\hline Project planning & & & \\
& .635 & 30 & 5 \\
\hline Human Resource Management & .721 & 30 & 5 \\
\hline Environment or condition & .672 & 30 & 4 \\
\hline Midterm performance of project & .617 & 30 & 4 \\
\hline
\end{tabular}

Source: Fieldwork data, 2018

Before interpreting these results, it is necessary to specify that the value of the alpha coefficient is between 0 and 1. The higher the value of Alpha Cronbach more items represent the same phenomenon. Nunnally (1978) recommends an Alpha greater than .60 to comment on the reliability of the measurements. The Cronbach's alpha coefficients are satisfactory for all of our variables since they are all greater than .60 which indicates good homogeneity of our constructs.

Factor analysis: Factor analysis attempts to identify the factors that explain correlations in the interior items. Before starting the factor analysis, it is advisable to measure the sampling adequacy by the Kaiser-Meyer- Olkin coefficient (KMO) which assesses the extent of the psychometric relation of the items. Items can be factorized as soon as the value of the KMO exceeds .50 Kaiser and Rice (1974).

Table 3

Kaiser-Meyer-Olkin coefficients (KMO)

\begin{tabular}{lccc}
\hline Variables & $\begin{array}{c}\text { Coefficient of } \\
\text { KMO }\end{array}$ & Meaning of Bartlett & Number of Items \\
\hline Project planning & .605 & .000 & $\mathbf{5}$ \\
\hline Human resources management & .565 & .000 & $\mathbf{4}$ \\
\hline Environment & .665 & .001 & $\mathbf{4}$ \\
\hline The performance midterm projects & .573 & .000 & $\mathbf{4}$ \\
\hline
\end{tabular}

Source: Fieldwork data, 2018

The KMO coefficients are satisfactory for all of our variables since they are all greater than .50 , so factorial analysis is possible.

\section{Verification of research hypotheses}

The verification of our research hypotheses was carried out by performing at first an analysis of correlations between the independent variables and the dependent variable (for three first hypothesis), and secondly by performing correlation analyzes in control (for the fourth hypothesis).

Checking the first and second hypotheses: Our first hypothesis assumed the existence of a relationship between each of the performance factors linked to the internal management of the project on the one hand and the performance of development projects in Burkina Faso on the other. To test this hypothesis, we proceeded to an analysis of correlations bivariate to using the Pearson correlation coefficient given the reasonable sample size $(n>30)$ and the normal distribution of our variables. This test is also the most suitable method when it comes to measuring the linear relationship between two variables measured with metric scales. The 
analysis of the bivariate correlations (Table 3 ) shows us that at the $5 \%$ level, the two independent variables are positively and significantly correlated with the performance of development projects. These are respectively the "Project planning" variable and the "Human resources management" variable. The independent variable that has the strongest correlation with the performance at mid-term project is the variable "Project Planning" $(r=.565, p<.021)$. In addition, the "Human Resources Management" variable shows significant correlations with all the other independent variables.

Table 4

Correlation Matrix (Pearson)

\begin{tabular}{|c|c|c|c|c|}
\hline & & $\begin{array}{l}\text { REGR factor } \\
\text { score } 1 \text { for } \\
\text { analysis } 1 \\
\end{array}$ & $\begin{array}{l}\text { REGR factor } \\
\text { score } 1 \text { for } \\
\text { analysis } 2 \\
\end{array}$ & $\begin{array}{c}\text { REGR factor } \\
\text { score } 1 \text { for } \\
\text { analysis } 4\end{array}$ \\
\hline \multirow{3}{*}{$\begin{array}{l}\text { REGR factor } \\
\text { score } 1 \text { for } \\
\text { analysis } 1\end{array}$} & Pearson Correlation & 1 & $.379^{*}$ & $.565^{*}$ \\
\hline & Sig. (2-tailed) & & .042 & .021 \\
\hline & NOT & 30 & 30 & 30 \\
\hline \multirow{3}{*}{$\begin{array}{l}\text { REGR factor } \\
\text { score } 1 \text { for } \\
\text { analysis } 2\end{array}$} & Pearson Correlation & $379^{*}$ & 1 & $.345^{*}$ \\
\hline & Sig. (2-tailed) & .042 & & .043 \\
\hline & NOT & 30 & 30 & 30 \\
\hline \multirow{3}{*}{$\begin{array}{l}\text { REGR factor } \\
\text { score } 1 \text { for } \\
\text { analysis } 4\end{array}$} & Pearson Correlation & $.565^{*}$ & $.345^{*}$ & 1 \\
\hline & Sig. (2-tailed) & .021 & .043 & \\
\hline & NOT & 30 & 30 & 30 \\
\hline \multicolumn{5}{|c|}{ *.05 level (2-tailed). } \\
\hline \multicolumn{5}{|c|}{ **.01 level (2-tailed). } \\
\hline
\end{tabular}

\section{Source: Fieldwork data, 2018}

\section{Verification of the third hypothesis}

Our second hypothesis assumed the existence of a relationship between the project environment on the one hand and the performance of development projects in Burkina Faso on the other. A like checking the first hypothesis, we proceeded to an analysis of correlations bivariate to using the correlation coefficient of Pearson, to check the third hypothesis; It appears that the $5 \%$ threshold, the variable has a positive and significant influence on the performance in development projects $(\mathrm{r}=.195, \mathrm{p}<.024)$. See Table $\mathrm{n}{ }^{\circ} 5$.

Table 5

Correlation Matrix (Pearson)

\begin{tabular}{|c|c|c|c|}
\hline \multicolumn{4}{|c|}{ Correlations } \\
\hline & & $\begin{array}{c}\text { REGR factor score } 1 \\
\text { for analysis } 3\end{array}$ & $\begin{array}{l}\text { REGR factor score } 1 \\
\text { for analysis } 4\end{array}$ \\
\hline \multirow{3}{*}{$\begin{array}{l}\text { REGR factor score } 1 \\
\text { for analysis } 3\end{array}$} & Pearson Correlation & 1 & $.195^{*}$ \\
\hline & Sig. (2-tailed) & & .024 \\
\hline & NOT & 30 & 30 \\
\hline \multirow{3}{*}{$\begin{array}{l}\text { REGR factor score } 1 \\
\text { for analysis } 4\end{array}$} & Pearson Correlation & $.195^{*}$ & 1 \\
\hline & Sig. (2-tailed) & .024 & \\
\hline & NOT & 30 & 30 \\
\hline *. .05 level (2-tailed). & & & \\
\hline **.01 level (2-tailed). & & & \\
\hline
\end{tabular}

\section{Checking the Fourth Hypothesis}

$$
\text { Source: Fieldwork data, } 2018
$$

In order to verify the relationship between the performance factors and the performance midterm development projects in Burkina Faso varies depending on the type of focus area of the 
project, we conducted a correlation analysis between independent variables and the dependent variable for each of the areas of intervention. We used Spearman's correlation since this method is most appropriate when the number of cases is very small $(\mathrm{n}<30)$. The control of each project organizational structures was achieved in using the function Select boxes-if, permitted by SPSS software, choosing to each organizational structure to control. The results of these analyzes are presented in the table below.

Table 6

\begin{tabular}{cccc} 
Correlations (Spearman) & Under Control of the Intervention Domain & \\
\hline Variables & $\begin{array}{c}\text { REGR factor score 1 } \\
\text { for analysis 1 }\end{array}$ & $\begin{array}{c}\text { REGR factor score 1 } \\
\text { for analysis 2 }\end{array}$ & $\begin{array}{l}\text { REGR factor score 1 } \\
\text { for analysis } 3\end{array}$ \\
\hline
\end{tabular}

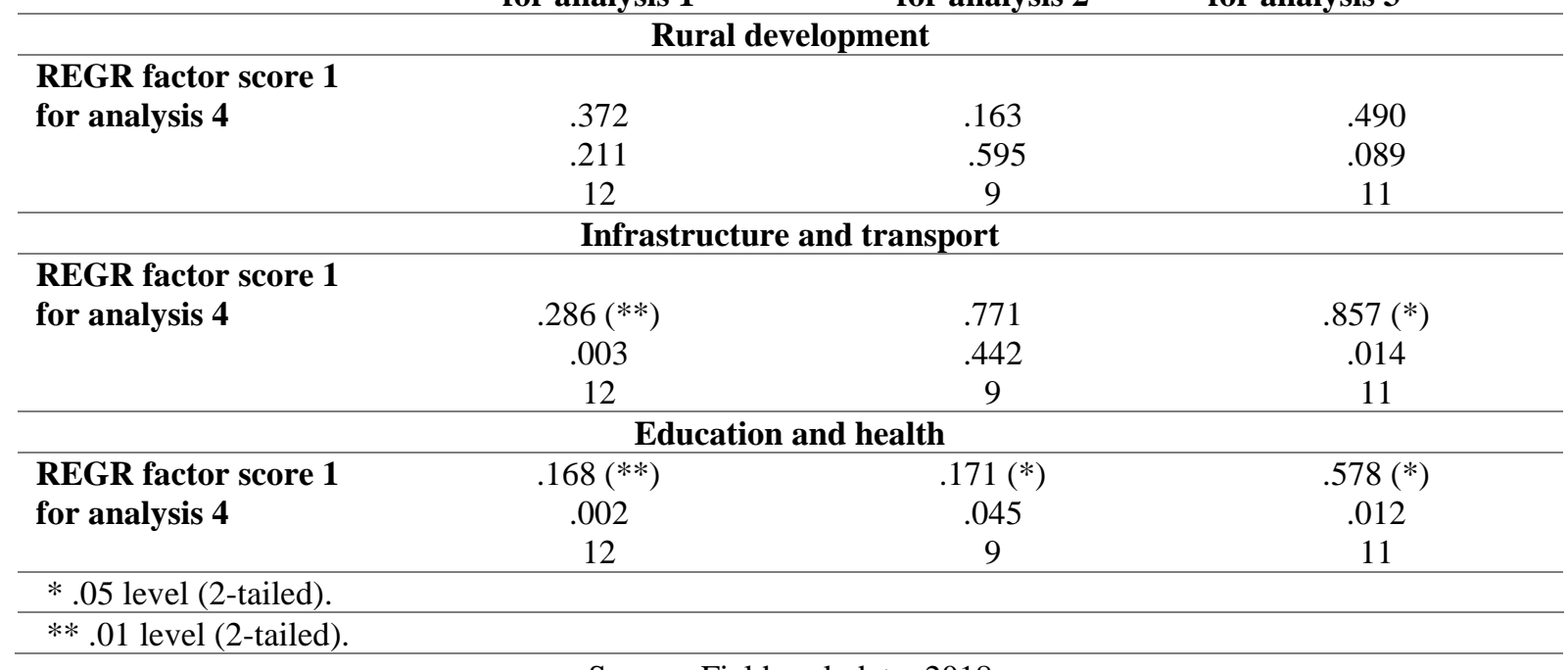

Source: Fieldwork data, 2018

The results of correlation analyzes under the control of the areas of intervention have shown that in the field of rural development, no factor significantly influences the mid-term performance of projects. In the area of infrastructure and transport, HRM is the only factor that has no significant correlation with the mid-term performance of projects. The other factors all have a moderate to strong correlation with the mid-term performance of the projects. The strongest correlation in this domain is in particular the "environment" variable $(r=57.8 ; \mathrm{p}<$ .001). Regarding the field of education and health, all independent variables are significantly correlated with the performance at mid-term development projects in Burkina Faso.

\section{The Influence of the Project Planning Variable}

\section{DISCUSSION OF RESULTS}

This variable has the expected sign. Project planning is positively correlated with the level of project performance. In this regard, it is often suggested that methodological differences between studies may have been largely responsible for the conflicting results reported in the literature, as well as for the debate regarding the value of planning (Dean \& Sharfman, 1996). The results of our research strongly support the usefulness of project planning as a process of gathering relevant information for creating and maintaining project alignment with its internal and external environments. Thus, Project planning appears to be a process that effectively makes it possible to rationally determine a favorable strategic direction for the organization and to facilitate the company's adaptation to changes in its environment (Porter, 1996). Given the turbulence of the environment, planning can help companies to avoid costly mistakes and to survive in environ highly competitive costs (Aram \& Cowen, 1990). It is 
evident that there is a positive relationship between the planning that is done in a business and the results that that business is capable of achieving. The lack of planning in a business is a one of the causes of bankruptcy. At least three reasons could explain the positive impact of planning on performance:

- First, the rational process helps decision makers to effectively manage the complexity inherent in strategic decisions makers must address in a number of important issues related to opportunities and to threats facing such a situation, a comprehensive decisionmaking is likely to lead to better decisions and outcomes Dean and Sharfman (1996).

- Second, the comprehensive process helps decision makers to reduce some effects of cognitive biases. Beyond a general difficulty in understanding a complex situation, these biases are often the source of problems, for example, policymakers seeking information in the wrong places, focus on erroneous information, and ignore some important information.

- Third, the comprehensiveness of the decision-making process strengthens the motivation and the commitment of decision-makers in the implementation of the strategy. The study results correspond to the research results of Bande and Nassè (2020) according to which, projects carried out according to clearly defined and planned processes have a better chance of success. According to these authors, prior and rigorous planning of the objectives to be achieved, as well as good procedures for adapting to any changes during the project, promote the performance of development projects. Planning is of utmost importance to the manager of a project, which emphasized during the interview.

"Despite the uncertainties in the field, adherence to plans is essential to achieve time-to-market objectives. But the norm is that a project moves over time and the various contingencies that can arise at any time".

In addition, the efficient use of project resources remains very decisive in relation to its performance. This finding is consistent with the results of the study by Bande and Nassè (2013) which demonstrates that the assurance and the use of resources are positive factors for the realization and performance. On this point, a project manager insists on the role of the availability of material and budgetary resources by affirming:

" That we must have the necessary budgetary resources because of the normal existence of deviations. Budget variances cause development projects to fail, so adjustment mechanisms and flexibility are needed".

\section{The Influence of the Human Resources Management Variable}

The Human Resources Management variable is positively correlated with the level of performance of development projects. The most proficient problem-solving project managers are those who are able to delegate authority, motivate, develop the skills of their team members and manage resources in an effective and efficient manner. In addition, our results support studies carried out in developing countries which confirm the existence of a positive effect of HRM on project performance, at least by confirming the positive and significant relationship that exists between these two variables (Youker, 1999; Khang and Moe, 2008; Diallo and Thuillier, 2005). We can thus conclude that, in a context as specific as that of developing countries, the relationship between HRM and project performance does not differ from that 
observed in the more global context analyzed in the framework of the studies by Belout and Gauvreau (2004). Our results thus reinforce the results of the various studies affirming the role of HRM in the success or failure of projects, both in the specific context of developing countries and in a more global context. On this point, a project manager insisted on the role of Human Resources Management in these terms:

\section{" The leadership skills of the project manager would play an essential role in his ability to manage resources, to delegate some of these powers and responsibilities, to develop and motivate the members of his team, etc. "}

Some conditions necessary for an R \& D organization teams, include getting a good academic training, and being intelligent and creative ability to put to use the knowledge generated by the ecosystem for innovation. Therefore, the capacity of the project team to integrate knowledge from the outside helps to stimulate the internal innovation process of companies. Indeed, the manager of a project pointed out during the interview.

\section{"In our team, we have doctors, engineers in fields as diverse as sociology, project management, technicians of the environment. All these internal human resources allow us to benefit from university knowledge".}

It is important to remember that our conclusions, relating to the existence of a relationship between HRM and the performance of projects in developing countries, are based solely on the results of correlation analyzes. However, the studies of Belout and Gauvreau (2004) who took the analysis further by performing regression analyzes, revealed that, despite the existence of a significant correlation between HRM and project success, the "Staff" or HRM factor does not have a significant impact on project success. It is of course recognized that regression analyzes are more robust than correlation analyzes, from an inferential point of view, when it comes to studying the effect of an explanatory variable on a variable to be explained. As part of our research, we were not able to proceed to the regression analyzes to because of the size of our sample. Thus, it will not be possible to make a comparison with the results of studies by Belout and Gauvreau (2004) and Pinto and Prescott (1988) nor to confirm or deny the existence of an impact of HRM practices on performance. It is to be noted also that these authors recognize the existence of certain methodological limitations that explain the results obtained in their regression analyzes. Indeed, according to Pinto and Prescott (1988), the results of their study, which reported that HRM does not have a significant impact on project performance, could be explained by the indicators used to measure the construct "HRM ". This explanation was also put forward in the framework of the study by Belout and Gauvreau (20002004) who recognize that the construct developed to measure the impact of HRM on the performance of projects is not sufficiently developed to provide irrefutable results. In addition, the size of the sample used in their study (compared to the relatively large number of independent variables and moderator variables involved in the regression analyzes) could also explain the surprising results of the regression analyzes relative to the impact of HRM on project performance. They add as an explanation the difficulty, encountered by all the studies carried out in this field of research, of measuring the impact of HRM on the performance of organizations. 


\section{The Influence of the Environment Variable}

Regarding the environment or project condition variable, it emerges that at a threshold of 5\%, the variable has a positive and significant influence on the performance of each project in said zone. This result is consistent with the work of De Medeiros (2007) on agricultural projects in Brazil, who succeeded s to the conclusion that project performance increases with the number of partners. The projects between them constitute real partners at the local level. This situation could be explained by the spillover effects and complementarity between projects and learning in the beneficiary community. The environment is considered of paramount importance by the project manager, who underlined during the interview:

\section{"The more a locality of the country receives projects, the more they are efficient in this locality".}

Indeed, for some time, especially in starting the implementation of the Paris Declaration in 2005 and the Partnership Bussan in 2012, the Government of Burkina Faso is working for a division of labor among development partners, focusing on complementarity. Pooled funds and joint evaluations which have become increasingly important nowadays encourage the implementation of complementary projects. The learning effects relate to the acquisition of skills by the local community in relation to the experienced projects. Thus, the more projects a region receives, the more the local population learns from experience, and the better the execution of local projects improves. In Burkina Faso, this reality can see in through the fact that the capacity of communities to the base to support the project as a criterion of choice for its implementation. This result is also in line with the conclusions of several studies.

Finsterbusch and Van Wicklin (1989) have demonstrated the benefits of community participation in the success of development projects. In Burkina Faso, this result could be explained by the fact that the associations constitute a channel for carrying out certain activities essential for the project. These activities which mainly aim to reach communities relate to communication, mobilization and awareness. Given the comparative advantage of organizations in these activities, their presence in a place is beneficial projects, including those focus on awareness and community mobilization.

\section{"As part of the implementation of our activity planning. In addition, to our team, we benefit from the support of associations which facilitate our actions in the field".}

Sector of execution: The performance sector (or area of intervention) was used in the study by Belout and Gauvreau (2004) as a moderating variable that intervenes in the relationship between HRM (as well as the other factors of their model) and the success of the projects. Based on this study and on other studies that suggest the importance of considering the moderating effect of the intervention area to better understand the relationship between performance drivers and performance at mid-term project, we hypothesized that the relationship between the factors and performance to mid-term development projects in the P E D will be different depending on the area of intervention. The results of our research confirm this hypothesis since the factors that showed significant association with the performance at mid-term projects vary from one sector to another. Indeed, in the field of rural development, all factors showed a significant 
correlation with the performance at mid-term projects with the exception of "HRM". On the other hand, in the area of infrastructure and transport, the "Planning" factor is the only one that shows a significant association with the performance of development projects. Finally, in the field of education and health, only the environment variable is significantly correlated with the performance of development projects.

The findings are in line with the results of Belout and Gauvreau (2004) suggested the importance of taking into account the moderating effect of the field of intervention in the study of the success factors of projects. Surprisingly, and contrary to the results of Belout and Gauvreau (2004), HRM showed significant correlation with the performance at mid-term development projects in any of the areas as part of our sample.

This result is different from that found in the study by Belout and Gauvreau (2004). Also, the study carried out as part of Dolan's thesis (2005), led to the same result as that of Belout and Gauvreau (2004) with regard to the field of computer science. Our result, which differs from that of previous studies, could be explained by the insufficient number of projects included in the sub-samples relating to each of the sectors studied. It would be appropriate in future research to repeat the exercise by involving a much larger sample for the different sectors of activity. Also, it would be interesting to conduct studies by industry, to like studying Dolan (2005), involving large enough samples to get more valid results.

\section{CONCLUSION AND RECOMMENDATIONS}

Conceptual contributions: The present research has contributed to the enrichment of concept such as the concept development project, the concept of mid-term performance, and the concept of performance through a review of the literature on these concepts.

Managerial contributions: This research has shown that the context is quite important as it plays a determining role in projects' performance. The availability of associations, projects and educational attainment of the locality have a significant effect on the mid-term of development projects. Thus, Project Managers may use procurement plans in order to monitor deadlines and the implementation of monitoring dashboards. This could help them to make corrections at the right time and at the right place. Control system also should be implemented before the calls for tenders. There should also be a training for the technical and professional staff for a good efficiency in performing the task appropriately. Finally, there is also a need to intensify research projects for project teams in order to meet the needs of organizations which will be more and more numerous. The management of human resources that support development projects remains embryonic and it requires a deep exploration to understand and develop best managerial practices that are specific to the context.

Future research: There is a need to carry out this research within the context of other countries to see if the result will be the same.

\section{References}

Aram, J. D., \& Cowen, S. S. (1990). Strategic planning for increased profit in the small business. Long Range Planning, 23, 63-70

Bande, R. S., \& Nassè, T. B. (2020). Development communication and performance in the projects of low-income countries: the case of the regional support project for pastoralism in the sahel (PRAPS) in Niger. International Journal of Management \& Entrepreneurship Research, 2(5), 380-390. 
Belout, A., \& Gauvreau C. (2004). Factors influencing project success: the impact of human resource management. International Journal of Project Management, 22(1), 1-11.

Bessette, G. (2004). Communication et participation communautaire: Guide pratique de communication participative pour le développement. Les Presses de l'Université Laval

Bouckaert, G., \& Halligan, J. (2008). Managing performance. International comparisons. London, LO: Routledge.

Bourguignon, A. (2000). Performance et contrôle de gestion. Encyclopédie de Comptabilité, Contrôle de Gestion et Audit, Ed. Economica.

Carbonell, N., Nassè, T. N., Ouédraogo, A., Kafimbou, B. H., Ampofo, J. A, \& Kinda, M. (2020). Recruitment methods and performance: an evidence from businesses in Burkina Faso. International Journal of Management \& Entrepreneurship Research, 2(4), $262-$ 272.

Cohanier, B., Lafarge, P., \& Loiseau, A. (2010). Management de la performance: des représentations à la mesure. Rouen, RO: Rouen Business School.

Dean, J. W. Jr., \& Sharfman, M. P. (1996). Does decision process matter? a study of strategic decision-making effectiveness. The Academy of Management Journal, 39(2), 368-396.

De Medeiros, L.S. (2007). Social movements and the experience of market-led agrarian reform in Brazil. Third World Quarterly, 28(8), 1501-1518,

Descheemaekere, C. (2013). La méthode PRINCE 2: réussir les certifications fondamental et praticien. Paris, PA: Dunod.

Diallo, A., \& Thuillier, D. (2005). The success of international development projects, trust and communication: An African perspective. International Journal of Project Management, 23(3), 237-252.

Dolan, K. (2005). Critical success factors in information technology project management. Montréal, MO: Mémoire de M. Sc., Université de Montréal.

Finsterbusch, K. \& Van Wicklin, W. A. (1989). Beneficiary participation in development projects: empirical tests of popular theories. Economic Development and Cultural Change, 37(3), 573-93

Gauthier, B. (2005). Problèmes d'incitations et aide au développement: une perspective institutionnelle. Management International, 9(3), 33 -50.

Gavard-Perret, M. L., Gotteland, D., Haon, C., \& Jolibert, A. (2008). Méthodologie de la recherche: réussir son mémoire ou sa thèse en science de gestion. Paris, PA: Édition Pearson Education

Infrastructure Québec (2013). La gestion des risques dans les mégaprojets d'infrastructure publique: Guide méthodologique.

Jacquet, S. (2011). Management de la performance: des concepts aux outils. CREG.

Kaiser, H. F. \& Rice, J. (1974) Little Jiffy, Mark Iv. Educational and Psychological Measurement, 34, 111-117.

Khang, D. B., \& Moe, T. L. (2008). Success criteria and factors for international development projects: a life-cycle-based framework. Project Management Journal, 39(1), 72-84.

Kiemtore, M. (2016). Développement d'une approche de management des mégaprojets d'investissement favorisant la performance: intégration des facteurs négligés. Québec QU: Thèse de doctorat, Université de Chicoûtimi. 
Lorino, P. (2003). Méthodes et pratiques de la performance: le pilotage par les processus et les

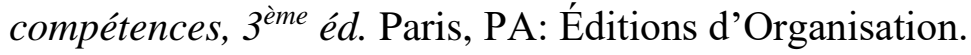

Mc Call, E. (2010). La communication pour le développement : accroître l'efficacité des nations unies. New York, NY: United Nations Development Program.

Nassè, B. T. (2018). Pratiques religieuses et comportement de consommation dans un contexte africain: une étude exploratoire sur les consommateurs au Burkina Faso. Thèse de Doctorat en sciences de Gestion, spécialité marketing. Ouagadougou, OU: Université Aube Nouvelle et Université Cheikh Anta Diop.

Nassè, B. T. (2016). L'équité interne dans la gestion de la relation client: une étude comparative quantitative de trois entreprises privées du Burkina Faso. Journal Ouest-Africain des Sciences de Gestion, 1(1), 38-54.

Nassè, T. B. (2015). Internal equity as a factor of companies' economic profitability: A comparative study of three private companies in Burkina Faso through a qualitative approach. Saarbrucken, SA: Lambert Academic Publishing.

Nunnally, J. C. (1978). Psychometric theory ( $2^{\text {nd }}$ ed.). New York, NY: McGraw-Hill.

Pinto, J. K., \& Covin, J.G. (1989). Critical factors in project implementation. Technovation, 9(1), 49-62.

Pinto, J. K., \& Prescott, J. E. (1988). Variations in critical success factors over the stages in the project life cycle. Journal of Management, 14(1), 5-18.

Porter, M. E. (1996). What is strategy? Harvard Business Review, 74, 61-78.

Prudhomme, A. (2006). Les bureaux de projets au Québec: Une étude descriptive. Rimouski, RI: Mémoire de maîtrise, Université du Québec A Rimouski.

Slevin, D. P., \& Pinto, J. K. (1986). The project implementation profile: New tool for project managers. Project Management Journal (September), 57-70.

Youker, R. (1999). Managing international development projects-lessons learned. Project Management Journal, 30 (2) 6-7.

\section{Acknowledgements}

The research team is grateful to Pr. Alidou Ouédraogo (for his sound supervision) and to Dr. Théophile Bindeouè Nassè, the associate editor of the International Journal of Management \& entrepreneurship research for his steady support and contributions.

\section{Conflicts of Interests}

No conflict of interest has been declared by the authors. 